\title{
Application of Bosnia $v$ Serbia to the Individualist Charge of Ineffectiveness: A Defense of State Responsibility
}

\author{
Felix Lambrecht* \\ University of Victoria \\ lambrecht.felix@gmail.com
}

\begin{abstract}
This paper aims to combat the individualist challenge to the notion of state responsibility in international law. That is, this paper attempts to counter the criticism of international law that suggests responsibility for wrongful acts should be attributed to individuals rather than states. While prior scholarship has focused on the individualist's fairness complaint, this paper focuses on the charge of ineffectiveness that would remove states as the primary duty-bearers in international law. By using the International Court of Justice case of Bosnia v Serbia (2007), this paper demonstrates that there are long-term important obligations in the international system that require states to remain primary duty-bearers in international law.

Keywords: State responsibility; individualist challenge; collective responsibility; International Court of Justice; Responsibility to Protect.
\end{abstract}

W ithin the philosophy of international law, there is considerable discussion about the nature of state responsibility, often centring on the question of who should have to pay for the wrongful actions of a state. These questions of repair should be resolved if international law is to become more developed moving forward. As will be explored in this paper, resolving this question is significant for the prevention of large-scale wrongful state actions such as genocide and aggressive warfare. Although customary international law requires that the wrongfully-acting state must collectively repair damages that are consequences of state action, some in the international community view this model as problematic and suggest a model of state responsibility that focuses on individuals rather than states. This view of responsibility that suggests re-working the international legal system to focus on individuals is called the "individualist challenge" and has been put forward by prominent legal scholars such as Antonio Cassese (2005) and Philip Allott (1988). As will be demonstrated in this paper, although the individualist challenge aims to resolve issues in international law, it is ultimately flawed.

In this paper,0 I will apply the International Court of Justice (ICJ) case decided in 2007 of the Application of the Convention on the Prevention and Punishment of the Crime of Genocide (Bosnia and Herzegovina v. Serbia and Montenegro [henceforth Bosnia v Serbia]) to the framework of collective state responsibility outlined by James Crawford and Jeremy Watkins (2010). This paper uses Crawford and Watkins' (2010) framework of collective responsibility as it offers a comprehensive account, both empirically and philosophically, of how responsibility is attributed in the international system. Moreover, this paper uses Bosnia v Serbia (2007) since it is the landmark case used to strengthen the responsibility put on states for preventing genocide and frames the discussion of state responsibility as international law develops. That is, since Bosnia $v$ Serbia offers a new and stronger interpretation of state responsibility (Schabas, 2008), I use it to argue that international law requires collective responsibility in order to better prevent crimes like genocide. Using the ICJ

*I would like to thank Dr. Cindy Holder for her support and advice throughout the writing of this paper. 
judgement, I defend against the charge of ineffectiveness that challenges collective state responsibility. Specifically, I argue that the ICJ's strong interpretation of the obligation to prevent genocide implies a need for long-term obligations that can only be effective if states are the primary duty-bearers of international law. In addition, I present parallels between Catherine Lu's (2011) discussion of collective responsibility in the Japanese-Korean conflict and Bosnia v Serbia to demonstrate that collective state responsibility (rather than individual responsibility) is needed to address issues such as social structures and state proxies that are apparent in Bosnia v Serbia. Furthermore, to support my argument for collective responsibility and states being the primary duty-bearers in international law, I show that the developing doctrine in international law - the responsibility to protect - is contingent upon collective responsibility. This discussion of the responsibility to protect is framed with reference to prominent scholars such as Buchanan (2013), Forlati (2011), Turns (2007), and Winklemann (2010).

In this paper, first, I explain Crawford and Watkins' (2010) framework of state responsibility. Second, I will present the individualist challenge and the charge of ineffectiveness. Third, I will summarize the key points in Bosnia v Serbia (2007) and demonstrate that the ICJ's ruling supports Crawford and Watkins' argument against the individualist challenge, and I will use further literature, such as Lu's (2011) discussion of collective responsibility and literature discussing the Responsibility to Protect, to argue for collective responsibility with states as the primary duty-bearers in international law. Finally, I will discuss possible objections to this argument against the individualist challenge, referring to scholarship from Buchanan (2013) and Forlati (2011).

\section{A Model of State Responsibility}

In characterizing state responsibility, Crawford and Watkins (2010) point out that the international legal system operates on a civil, rather than a criminal, system. They explain that when a state performs a wrongful act, the framework that is imposed on the "delinquent" state is purely reparative rather than punitive (p. 286). This approach requires that any unlawful act done by a state results in both an obligation to cease and an obligation to repair. The obligation to cease the unlawful action demonstrates that international wrongful acts are ones that are disallowed or forbidden. This contrasts with wrongful actions which can be committed so long as the actor pays (or repays) the right price; rather, internationally wrongful action cannot ever be done. The obligation to repair requires the responsible state to undo the consequences of the wrongful act (where possible) and offer reparations to restore the status quo ante (the situation before the law was broken). Crawford and Watkins note that often a literal restoration to the status quo ante is impossible in cases of international wrongful acts, but nonetheless either financial compensation or apologies are implemented in order to provide some reparation (pp. 286-287).

Based on this underlying civil system of state responsibility that focuses on reparations for forbidden unlawful acts, Crawford and Watkins (2010) explain how state responsibility is attributed. They argue that because international state responsibility is grounded in the obligation to repair forbidden acts, losses that are suffered as a result of these forbidden acts should not "lie where they fall" (p. 286). In other words, they insist that since an internationally wrongful act is going to result in losses for a state, the burden of cost for reparation for these losses must be shifted onto the responsible state, a process they refer to as "loss-shifting" (p. 286). In addition to providing victims of wrongful acts with security and compensation, this loss-shifting serves to illustrate that the "freedom of action" of certain states is outweighed by the importance of certain kinds of individual rights (Crawford \& Watkins, 2010, p. 287). For instance, by signing the UN Convention Against Torture, the United Kingdom (among other nations) expressed that the remedial rights that incur from torture and the protection against torture were more important than the freedom of action in 
certain respects (namely, the freedom of action to extradite to nations where individuals might be tortured) (Crawford \& Watkins, 2010, pp. 287-288). This demonstrates that loss-shifting acts as both a security for potential victims of international wrongful actions and a normative judgement that the prohibition of certain actions is more important than state freedom of action.

This loss-shifting is integral to Crawford and Watkins' (2010) view of the rules of attribution in international law. They note that states can only truly act through the agency of individuals (p. 287). So, any action by an actor who is considered a public official under national law counts as an action of the state itself, and thus the state would be responsible for the action. The contrast to this view of attribution is a "controlling mind" view of responsibility in which only the direct actions of national leaders would count as the state's actions (Crawford \& Watkins, 2010, p. 288). However, Crawford and Watkins point out that this controlling mind model would actually result in more unremedied losses because it would reduce the number of agents who would count as state actors and thus reduce the legal necessity of loss-shifting (p. 288). In other words, because the international liability system is a civil model that focuses on repair though loss-shifting rather than punishment, the international legal system's rules of attribution are cast in a way that makes more actors bound as subjects of state responsibility, and thus the international system allows for the maximum cases that can give rise to remedial rights (Crawford \& Watkins, 2010, p. 288).

\section{The Individualist Challenge}

In response to this framework of state responsibility in which a state repairs damages of wrongful acts through interstate loss-shifting, some critics propose the "individualist challenge" (Crawford \& Watkins, 2010, p. 289). One proponent of the individualist challenge is the prominent legal scholar Antonio Cassese (2005) who argues that international law is "archaic" and "primitive" in that it forces the entire population of a wrongfully acting state to pay for the state's wrongful actions (p. 241). This challenge generally involves two steps that argue for a more individualized model of blameworthiness: the fairness complaint and the charge of ineffectiveness. The fairness complaint insists that the loss-shifting aspect in state responsibility is unjust to the populations in a state that committed an internationally wrongful act because there are almost certainly members of the state who are morally blameless for the actions of the state (Crawford \& Watkins, 2010, p. 290). As a result, an individualist would argue, the international legal system ought to introduce a more individualized aspect of state responsibility. Likewise, the charge of ineffectiveness, put forward by Philip Allott (1988), argues that international noncompliance is a result of international law speaking more to states than to individuals, thus allowing public officials and leaders to distance themselves from internationally wrongful acts (p. 14). As a result, an individualist may argue, individuals, as opposed to states, ought to become the primary duty-bearers of international law.

Although Crawford and Watkins (2010) set aside this charge of ineffectiveness in order to focus on combating the fairness complaint, in this paper I attempt to combat the individualist's charge of ineffectiveness. As explained above, one consequence of the ineffectiveness challenge is the suggestion that individuals, rather than states, should be the primary duty-bearers in international law. Before setting aside the charge of ineffectiveness to focus on the fairness complaint throughout the rest of their article, Crawford and Watkins offer suggestions for how their framework could be used to combat the charge of ineffectiveness in future scholarship. One offered suggestion is to demonstrate that there are benefits for states rather than individuals being the primary duty-bearers of the international legal system (p. 292). One such benefit could be that certain goals would require longevity that an individual leader or regime could not provide. That is, a demonstration of long-term obligations in international law would require the longevity of a state, which in turn would require states to be the primary duty bearers of international law (Crawford \& Watkins, 2010, 
The Arbutus Review • 2017• Vol. 8, No. 1 • http://dx.doi.org/10.18357/tar81201716803

p. 292). I believe that the ICJ judgement of Bosnia v Serbia (2007) can be used to demonstrate this kind of long-term obligation, and following Crawford and Watkins' suggestion to demonstrate that states do have long-term obligations that require them to remain the primary duty-bearers of international law, I use Bosnia v Serbia to combat the individualist's charge of ineffectiveness.

\section{Bosnia v Serbia: A Demonstration of State-First Obligations}

The ICJ ruling centres on the ethnic conflict during the Bosnian War in 1992. With nationalist movements in neighboring countries Serbia and Croatia and desires in these countries for ethnic homogeneity, ethnically Bosnian Serbs attempted ethnic cleansing of Muslim populations in areas controlled by Bosnia, Serbia, and Croatia (Turns, 2007, pp. 400-401). While this process of ethnic cleansing did not always involve extrajudicial killings throughout the war, there were many cases of widespread killings, specifically at Srebrenica (Schabas, 2008). It is important to note that many of these killings were carried out by paramilitaries and proxies in what was perceived by many to be an attempt on the part of Serbian officials to distance themselves from the illegal acts (Turns, 2007, p. 401). In 1993, while the conflict was ongoing, Bosnia put forward a complaint to the ICJ that demanded Serbia be deemed responsible for the genocidal acts throughout the war (Bosnia v Serbia, 2007, p.1).

On February 26, 2007, the ICJ issued its ruling for the case of Bosnia v Serbia (2007). The applicant, Bosnia and Herzegovina, argued that Serbia had failed to act in accordance with the Convention on the Prevention and Punishment of the Crime of Genocide (henceforth "Genocide Convention"). Specifically, the ICJ ruled to determine whether Serbia committed genocide, was complicit in genocide, or failed to prevent genocide (Bosnia v Serbia, 2007). Ultimately, while the court concluded that Serbia did not commit genocide, nor was complicit in genocidal acts, it did rule that Serbia had failed to prevent genocide in Srebrenica. Specifically, I focus on one of the most significant features of the court's reasoning: that the obligation to prevent genocide extends to cases in which individuals are not necessarily state actors or have the "right" kind of connection with the state that would normally entail an obligation to prevent genocide (Schabas, 2008). That is, even if those who commit genocidal acts are not public officials, the state has an obligation to try to prevent or constrain, to the best of its abilities, any genocidal acts.

In order to reach this conclusion, the ICJ demonstrated a broad interpretation of the Genocide Convention. While the Genocide Convention does mention an obligation for states to "prevent" genocide, it does not elaborate as to how far this obligation extends (Clearwater, 2009). In the ICJ's ruling, the court expressed a broad interpretation of this obligation to prevent genocide: "for a state to be held responsible for breaching its obligation of prevention, it does not need to be proven that the State concerned definitely had the power to prevent the genocide; it is sufficient that it had the means to do so and that it manifestly refrained from using them" (Bosnia v Serbia, 2007, p. 158). The court here concluded that a state has the responsibility to attempt to prevent genocidal acts in any way possible. In other words, the court concluded that Serbia could, in theory, be held responsible for the failure to have prevented genocide even when the military committing genocide was not completely in Serbia's control or had the "right" state-actor relationship to Serbia (Schabas, 2008). As a result, the court's ruling indicates that merely an ability to have prevented (in some way) the genocidal acts is enough to entail an obligation to prevent such acts. Therefore, the ICJ's ruling strengthens the obligation to prevent genocide that is imposed on states.

While the ICJ judgement imposes a stronger obligation for states to prevent genocide, this does not mean that the obligation on individuals to prevent (or not commit) genocide is weakened. That is, the obligation for individuals to prevent genocide is not altered following the ICJ judgment; rather the obligation for states to prevent genocide is expanded (Bosnia v Serbia, 2007, p. 158). As 
Clearwater (2009) explains, this is because the ICJ is interpreting the obligations outlined by the Genocide Convention as constituting dual responsibility extending to states and individuals alike.

As William Schabas (2008) explains, the ICJ's ruling seems to fit into the progressively expanding doctrine of the responsibility to protect. Briefly, the responsibility to protect is a doctrine that makes the rights of state sovereignty (such as the right to non-intervention) conditional upon the state's ability to protect citizens from unpunished or unmitigated atrocities. In failing to protect its own citizens, therefore, a state would forgo the rights entailed by sovereignty (Winklemann, 2010). In other words, the responsibility to protect makes it a legal obligation for states to uphold the rights and safety of the individuals living inside the state. Should a state fail to provide this protection, international law would allow other states to intervene in order to restore the human rights and safety of the citizens (Winklemann, 2010). Because the ICJ ruling indicates the strengthening of the obligation to prevent genocide even when those committing the genocidal acts are not directly under the control of the state, Schabas insists that the ICJ's ruling supports the doctrine of the responsibility to protect that would ensure protection for individuals (2008). In other words, the ICJ's ruling that strengthens obligation on states to prevent genocide creates a general duty on states to prevent genocide.

Based on these implications, I suggest that the ICJ ruling that strengthens states' obligation to prevent genocide can be used to counter the individualist's charge of ineffectiveness. As noted above, one of the consequences of the charge of ineffectiveness is that it would make the primary duty-bearers of international law individuals rather than states. However, as Crawford and Watkins (2010) suggest, one way of combating this charge is by pointing out that there are long-term benefits to a system that takes states as the primary duty-bearers. The fact that the ICJ ruled to strengthen states' obligation to prevent genocide would require that states remain the primary duty-bearers in international law. That is, the fact that a state must be responsible for the prevention of genocidal acts indicates that there are long-term goals needed in order for a state to succeed in preventing genocide that would surpass the longevity of any individual regime. Moreover, the fact that this obligation to prevent genocide would be an ongoing obligation indicates that the state would continuously be responsible in the event of a regime change; the longevity of a state, as opposed to an individual, is required. So, in order for this obligation to prevent genocide, strengthened by the ICJ ruling, to be successfully upheld by a state, a state would have to be the primary duty-bearer of the long-term obligation.

In addition to this specific long-term obligation to prevent genocide, the ICJ ruling also offers the long-term obligation of the responsibility to protect. Since the ICJ judgement creates a stronger obligation on states to prevent genocide, this ruling indicates a step in the direction of the long-term goal that reinforces states' obligation to ensure a minimum level of human rights through the responsibility to protect. That is, the ICJ's strong interpretation of a states' obligation to prevent genocide is part of the developing doctrine that requires states to have a duty to protect human rights. As explained above, the goal is to be able to provide more security to citizens of states by requiring the state's sovereignty to be contingent on successfully upholding this duty of protection. But, if states were not the primary duty-bearers of international law, it would be more difficult to create the kind of obligation that would require them to ensure this minimum level of security. If individuals were the primary duty-bearers of international law, a general duty to protect and guarantee a minimum level of security and human rights within a state would be less feasible. In order to create the kind of long-term obligation that guarantees a minimum level of security for individuals within a state, states would have to be the primary duty-bearers of international law. Thus, not only does the ICJ's judgment demonstrate the need for long-term obligations for states to prevent genocide, but it fits into the long-term ongoing development of the responsibility to protect which requires states to provide a minimum level of human rights, both of which would require 
states to be the primary duty-bearers of international law.

One final way in which Bosnia v Serbia (2007) could be used to support an argument against the charge of ineffectiveness is by highlighting the structural aspects associated with the case. Although $\mathrm{Lu}$ (2011) focuses on a case of a structural injustice in which colonial actions were technically legal, her scholarship provides parallels to the case of Bosnia v Serbia in regards to how it can be used to reject the charge of ineffectiveness. Lu describes the unjust colonial acts committed by the Japanese government against the Korean people from 1910-45. She argues that an individualistic account of blameworthiness does not adequately capture the correct form of justice needed to repair and punish the acts that were a direct result of Japanese colonialism (pp. 269-70). Rather, she suggests, a structural injustice approach would better repair the injustices done and would change the structures in order to ensure that the injustices would not happen again (p. 271). Specifically, Lu argues that although the Japanese were the colonial power and were indeed guilty of many atrocities, Korean individuals and the Korean government itself supported and conducted many atrocities done to their own people. As a result, Lu thinks that blaming individual Japanese leaders and militants is not the correct method for repairing the atrocities committed as a result of colonialism, as this method would implicitly absolve other complicit or supportive Koreans (p. 271).

As Crawford and Watkins (2010) note, one vein of reasoning used with the charge of ineffectiveness is to argue that international noncompliance is a result of state leaders and officials knowing that they could distance themselves from the state and therefore avoid responsibility for internationally wrongful acts (p. 292). Consequently, this line of reasoning might argue that international law should make individuals the primary duty-bearers in order that state officials and leaders cannot avoid responsibility. However, I believe that Lu's (2011) discussion of the colonial acts illustrates that specifically targeting individuals with responsibility can implicitly absolve others who are complicit or supportive of atrocities. In the context of Bosnia $v$ Serbia, if one were to claim that certain individuals were the only ones responsible for the failure to prevent genocide, then one could be implicitly absolving others who were complicit in the failure to prevent genocide. This idea of implicitly absolving certain individuals reveals that the individualist's worry, that holding states responsible creates a way for guilty individuals to distance themselves from the state and avoid blame for internationally wrongful acts, is still a worry when individuals are made the primary duty-bearers of international law. That is, individuals would still be able to distance themselves from the wrongful act by ensuring that others were attributed primary blameworthiness, and thus be implicitly absolved. Following $\mathrm{Lu}$, I argue that making individuals the primary duty bearers in international law would actually allow precisely the same kind of distancing from the state and wrongful actions that it would be trying to avoid.

Another point in Lu's (2011) article that is worth noting is her emphasis on the reparation of social structures that is required in her model of responsibility. She insists that social structures (including attitudes and rhetoric) would need to be changed in order that atrocities do not repeat themselves. This idea of societal change is an example of a long-term goal that Crawford and Watkins (2010) suggest could be an element of a state-centric model of responsibility. The idea that social ideas within a state need to be changed in order that atrocities do not repeat themselves could be applied to rhetoric behind ethnic cleansing and religious persecution in the case of Bosnia $v$ Serbia (2007, p. 122). Since these ideas are based in structural rather than individual attitudes, following $\mathrm{Lu}$, I insist that an individual model of responsibility is not enough to enact the long-term societal change that would be necessary in order to change attitudes and, in turn, prevent genocide. Accordingly, in order to be able to enact this long-term societal change, states would have to remain the primary duty-bearers of international law.

A further structural argument can be made to demonstrate that states need to be the primary duty-bearers of international law. As Jamieson and McEvoy (2005) point out, the international legal 
system has developed a culture of using proxies in order for wrongfully-acting states to distance themselves from wrongful acts. This idea of distancing can be seen in Bosnia v Serbia (2007) in which the court and witness testimonies extensively discussed Serbia's use of paramilitaries (p. 139). However, while Serbia attempted to use paramilitaries in order to distance their wrongful actions from the responsibility of the state, the ICJ ruled that Serbia still had an obligation to prevent genocide, even when those committing genocidal acts were not state actors (p. 158). This ruling that requires states to be responsible for even non-state actors is a move to limit the amount of "othering" - the practice of states distancing illegal actions and actors from the government in order to avoid responsibility for an internationally wrongful act - that a state can do to avoid responsibility for an internationally wrongful act (Jamieson \& McEvoy, 2005, p. 505). In other words, the ICJ ruling demonstrates a desire to move away from a culture in international law that allows for distancing methods. Thus, the fact that Bosnia $v$ Serbia demonstrates a desire to move away from a culture of distancing methods could be used to combat the charge of ineffectiveness in two ways. First, moving towards a system that uses fewer proxies would be the kind of long-term structural change that requires the cooperation of states. Second, the fact that the ICJ judgement entails a wider scope of responsibility that does not allow distancing to avoid blame would actually result in fewer cases of unpunished or unmitigated wrongful acts, thus rendering the charge of ineffectiveness ineffective.

\section{Objections}

So far I have argued that the ICJ judgement of Bosnia v Serbia (2007) can be used to reject the individualist's charge of ineffectiveness in three ways. First, the ICJ ruling strengthens states' obligation to prevent genocide in such a way that states would have to remain the primary dutybearers of international law in order to effectively realize this long-term goal of preventing genocide. Second, the ICJ judgement fits into an ongoing long-term doctrine, the responsibility to protect, that would require a cooperation of state actors to be the primary duty-bearers if this doctrine that is intended to ensure a minimum level of human rights and security is to succeed. Third, Bosnia $v$ Serbia parallels other cases of international conflict in which structural solutions that require collective action are needed to prevent implicitly absolving guilty or complicit actors and in order to collectively change the culture of distancing from wrongful acts, both within domestic systems and the international legal system. I now briefly consider possible objections to my arguments against the charge of ineffectiveness: First, the objection that the ICJ judgement that strengthens states' obligation to prevent genocide will ultimately weaken the ability for individuals to be punished for genocidal acts, and second, the objection that the responsibility to protect, which requires states to be the primary duty-bearers in international law, is ultimately flawed and will result in abuses by states.

An individualist might argue that the ICJ's judgement that strengthens states' obligation to prevent genocide would inevitably weaken the responsibility for individuals not to commit or prevent genocide. The worry here is that if a public official committed (or failed to prevent) genocidal acts then the state, according to the ICJ judgement, would be the primary duty-bearer for this act and the individual would be (at least partially) absolved. However, as Clearwater (2009) explains, although the court did not fully explain its reasoning, it concluded that the objection that individual responsibility for preventing genocide would weaken rests on a poor interpretation of the judgement. Specifically, the court expressed a notion of dual responsibility; just because a state official committed (or failed to prevent) genocide, and thus the state is responsible, does not preclude the fact that the individual can also be held accountable qua individual. So, in light of this idea of dual responsibility, Clearwater (2009) argues that holding states directly responsible (as the ICJ judgement would 
allow) will strengthen the obligation to prevent genocide. That is, it would require both states and individuals to be responsible for the prevention of (and for not committing) genocide. As a result, the objection that a model of international law in which the states act as the primary duty-bearers would weaken individual responsibility can be rejected.

The second objection - that the responsibility to protect, which requires states to be the primary duty-bearers in international law, is ultimately flawed and could result in abuses by states - is a controversial and heavily debated aspect of international law. For example, David Turns (2007) argues that the ICJ judgement in Bosnia v Serbia (2007) sets a stage that would allow states to intervene by invoking a responsibility to protect in such a way that could allow stronger states to prey on weaker states in order to further state goals. That is, because the responsibility to protect can be invoked when one state believes that another is not providing a minimum level of human rights and safety for individuals in that state, one worry is that some states could use the responsibility to protect to justify intervention that really has ulterior motives. In fact, many see Russian action in Ukraine as such an abuse of the responsibility to protect that is motivated by Russian interests, rather than the protection of rights and security of Ukrainians (see De Geest, 2015; Rudolph, 2014). However, for the purposes of this paper, I merely need to show that the responsibility to protect implied by Bosnia v Serbia does not necessarily entail abuses by states. Serena Forlati (2011) offers potential responses to this objection in light of the ICJ's judgement that strengthen states' responsibility to prevent genocide. For example, Forlati suggests that the international legal system could create specific standards of conduct for the prevention of genocide (pp. 202-205). That is, the international system could develop specific rules and guidelines that could outline the conditions necessary for a state to be entitled to intervene through claiming a responsibility to protect. Thus, according to Forlati, the responsibility to protect, properly developed, would not necessarily entail abuses by states. Others, such as Allen Buchanan (2013), agree that if the system were properly institutionalized, the risk of abuse would be minimized. Specifically, Buchanan thinks that one way of minimizing the risk of abuse with responsibility to protect is to institutionalize it in such a way that intervention on the grounds of protection would require the collective action of multiple state actors (p. 283). That is, Buchanan suggests that as long as the duties of states are properly articulated and require collective action, the risk of abuse would be minimized. Thus, the responsibility to protect does not necessarily result in abuses by states.

\section{Conclusion}

The ICJ judgement of Bosnia v Serbia (2007) strengthens the obligation for states to prevent and not commit genocide since it extends a state's obligation to using whatever means necessary for the prevention of genocide, even if that occurs outside the state's borders (pp. 156-158). Accordingly, I have argued that this judgment can be used to reject the individualist's charge of ineffectiveness since it creates long-term and ongoing goals that require longevity of states in three ways: by strengthening states' obligation to prevent genocide, by supporting the doctrine of the responsibility to protect, and by requiring collective action to change social structures and the culture of judicial distancing both domestically and internationally. Moreover, I have argued against the objection that Bosnia v Serbia demonstrates that the ICJ's judgement would inevitably weaken the responsibility for individuals to prevent genocide and the objection that the responsibility to protect entailed by Bosnia v Serbia necessarily results in abuses. In other words, because the findings in Bosnia v Serbia present a stronger responsibility for states to prevent genocide, the case supports the idea that states must undertake long-term efforts that individuals would be incapable of upholding. Since the charge

of ineffectiveness would require individuals, as opposed to states, to be the primary duty-bearers of international law, through the ICJ judgment I have argued that there are long-term obligations and 
goals that require states to be the primary duty-bearers of international law, and thus to reject the charge of ineffectiveness and the individualist challenge to state responsibility. Since individuals are incapable of upholding certain obligations in international law, as this paper has argued, collective state responsibility ought to remain the primary way of attributing responsibility in international law. 


\section{References}

Allott, P. (1988). State responsibility and the unmaking of international law. Harvard International Law Review, 29, 1-26.

Application of the Convention on the Prevention and Punishment of the Crime of Genocide (Bosnia and Herzegovina v. Serbia and Montenegro), Judgment, 2007, I.C.J. 191 (February 26).

Buchanan, A. (2013). The heart of human rights. Oxford, England: Oxford University Press.

Cassese, A. (2005). International law. Oxford, England: Oxford University Press.

Clearwater, S. (2009). Holding states accountable for the crime of crimes: An analysis of direct state responsibility for genocide in light of the ICJ's 2007 decision in "Bosnia v Serbia." Auckland University Law Review, 15, 1-41.

Crawford, J. \& Watkins, J. (2010). International responsibility. In S. Besson \& J. Tasioulas (Eds), The philosophy of international law. Oxford, England: Oxford University Press, 283-298.

Forlati, S. (2011). The legal obligation to prevent genocide. Polish Yearbook of Law, 31, 189-205.

De Geest, S. (2015). Russian intervention in Ukraine: R2P limits and reclaiming the concept. [website article]. Retrieved from http://www.hscentre.org/russia-and-eurasia/russian-interventionukraine-r2p-limits-reclaiming-concept-narrative/

Jamieson, R. \& McEvoy, K . (2005). State crime by proxy and judicial othering. The British Journal of Criminology, 45(4), 504-527.

Lu, C. (2011). Colonialism as structural injustice: Historical responsibility and contemporary redress. Journal of Political Philosophy, 19(3), 261-281.

Rudolph, J. P. (2014, March 7). How Putin distorts R2P in Ukraine. [website article]. Retrieved from https://www.opencanada.org/features/how-putin-distorts-r2p-in-ukraine/

Schabas, W. A. (2008). Application of the convention on the prevention and punishment of the crime of genocide case (Bosnia and Herzegovina v Serbia and Montenegro). In R. Wolfrum (Ed.), The Max Planck encyclopaedia of public international law. Retrieved from ॥ http://opil.ouplaw.com/view/10.1093/law:epil/9780199231690/law-9780199231690-e1245

Turns, D. (2007). Application of the convention on the prevention and punishment of the crime of genocide: Bosnia and Herzegovina v. Serbia and Montenegro. Melbourne Journal of International Law, 8(2), 398-427.

Winklemann, I. (2010) Responsibility to protect. In R. Wolfrum (Ed.), The Max Planck encyclopaedia of public international law. Retrieved from http://opil.ouplaw.com/view/10.1093/law:epil/978 0199231690/law-978 0199231690-e1464?prd=EPIL 